\title{
THE ANTIDIURETIC ACTIVITY OF PLASMA OF PATIENTS WITH HEPATIC CIRRHOSIS, CONGESTIVE HEART FAIL- URE, HYPERTENSION AND OTHER CLINICAL DISORDERS ${ }^{1}$
}

\author{
By MARVIN STEIN, ${ }^{2}$ ROBERT SCHWARTZ, AND I. ARTHUR MIRSKY \\ (From the Department of Clinical Science, University of Pittsburgh School of Medicine, \\ Pittsburgh, Pa., and The Medical Service, Veteran's Administration Hospital, \\ Aspinwall, $P a$.)
}

(Submitted for publication June 25, 1953; accepted September 23, 1953)

The retention of water which occurs in hepatic cirrhosis and in congestive heart failure has been attributed by some investigators to an increase in the concentration of circulating antidiuretic hormone of the neurohypophysis. In support of this hypothesis are the reports of a diminished diuretic response to the ingestion of water $(1,2)$ and of an increased antidiuretic activity of the blood or urine of patients with ascites and edema. Critical examination of such reports, however, reveals that the assay methods employed usually were neither sensitive nor precise (3) or that the number of subjects studied was too small for statistical evaluation (Table I).

The availability of a relatively simple, sensitive and precise bioassay in the rat for the measurement of antidiuretic activity (4) prompted the examination of the activity of the blood of patients with the aforementioned as well as with other clinical disorders.

\section{METHOD AND RESULTS}

Only men were selected for this study in order to obviate any possible influence of the menstrual cycle. The subjects selected to comprise the "healthy" group showed no apparent physiological or psychological disturbances. All patients with cirrhosis of the liver had ascites and edema. The patients with congestive heart failure had from ++ to ++++ edema. The blood pressures of the patients with hypertension were all beyond a systolic of $180 \mathrm{~mm}$. mercury and a diastolic of $100 \mathrm{~mm}$. mercury.

After a preliminary period of ten hours during which the subjects were not permitted to ingest food or water,

1 Reviewed in the Veteran's Administration and published with the approval of the Chief Medical Director. The statements and conclusions published by the authors are a result of their own study and do not necessarily reflect the opinion or policy of the Veteran's Administration.

2 U. S. Public Health Service Research Fellow of the National Institute of Mental Health. venous blood samples were drawn. The plasma was separated rapidly by centrifugation and assayed within one hour by the procedure described by Stein, Jinks, and Mirsky (4). Since previous studies revealed that the slope of the dose-response curve for plasma was essentially the same as that for pitressin and that this slope was fairly constant, only one dose of pitressin was used as the standard in each assay and the concentration of antidiuretic stubstance (ADS) in the plasma computed and expressed in terms of pitressin.

In brief, the assay procedure was as follows: After a preliminary fast of approximately 16 hours during which time the rats were permitted free access to water, $5 \mathrm{ml}$. of warm 0.2 per cent $\mathrm{NaCl}$ per 100 grams body weight were administered by stomach tube. One hour later, the gavage was repeated, and twenty minutes after the second gavage, $1 \mathrm{ml}$. of plasma per 100 grams body weight or a similar volume of a solution containing $0.6 \mathrm{mU}$ of pitressin in isotonic saline was injected intraperitoneally. The animals were handled and prodded every twenty minutes after the second gavage, and the volume of urine excreted at the 20 and 60 minute intervals was recorded. The response was expressed as the reciprocal of the ratio of the volume of urine excreted by 60 minutes to that excreted by $20 \mathrm{~min}$ utes after the second gavage. The mean response of five rats in individual metabolic cages was utilized to calculate the ADS potency of the plasma.

The antidiuretic activity of the plasma of 19 healthy men and of 108 men suffering from a variety of clinical disorders is depicted in Figure 1 and summarized in Table II. In the healthy group of men, the mean \pm S.E. antidiuretic activity of the plasma, expressed as pitressin equivalents, was $24.1 \pm 3.9 \mathrm{mU}$ per $100 \mathrm{ml}$. The individual values distribute themselves along a normal curve. The values for the patients suffering from various clinical disorders, however, vary markedly and are not distributed normally. Whereas the mean ADS value for each clinical disorder is greater than that of the healthy group, the median is quite similar to that of the healthy group (Table II). Accordingly, the majority of patients within each clinical group have values which are similar to those of the healthy individuals. Likewise, the plasma ADS values of approximately two-thirds of the subjects comprising all the clinical groups are within the range of those of healthy men. 


\section{DISCUSSION}

The procedure utilized in this study for the measurement of the antidiuretic activity of the plasma permits the detection of from 0.1 to 1.2 $\mathrm{mU}$ of pitressin per $\mathrm{ml}$. Consequently, many of the values obtained in normal men are just within the lower limits of the method. Since there are no other data in the literature in which the antidiuretic activity of the plasma is expressed in terms of pitressin equivalents, it is impossible to compare the range of values reported herein with those of other observers. The use of pitressin as a standard in the bioassay procedure and the quantitative expression of the antidiuretic activity of the plasma in terms of pitressin equivalents does not imply that the antidiuretic activity of the plasma is due to endogenous vasopressin.

The data reported herein do not support the hypothesis that the retention of water by patients with cirrhosis of the liver or by patients with congestive heart failure is related to an increase in the antidiuretic activity of the blood. Only 28 per cent

TABLE I

Summary of reports on the antidiuretic activity of blood and urine in various clinical disorders

\begin{tabular}{|c|c|c|c|}
\hline Disease entity & Body fluid & Results* & Reference \\
\hline Cirrhosis & Urine & $\begin{array}{l}+ \text { ADS in patients with ascites } \\
0 \mathrm{ADS} \text { in patients without ascites } \\
8 \text { patients and } 4 \text { normals studied }\end{array}$ & $\begin{array}{l}\text { Ralli, Robson, Clarke, } \\
\text { and Hoagland (5) }\end{array}$ \\
\hline Cirrhosis & Urine & $\begin{array}{l}+ \text { ADS in } 4 \text { patients } \\
+A D S \text { in rats with or without liver damage }\end{array}$ & $\begin{array}{l}\text { Hall, Frame, and Drill } \\
(6)\end{array}$ \\
\hline Cirrhosis & Urine & $\begin{array}{l}+ \text { ADS in } 50 \% \text { of } 22 \text { patients with ascites } \\
+ \text { ADS in } 35 \% \text { of } 22 \text { patients without ascites }\end{array}$ & $\begin{array}{l}\text { VanDyke, Ames, and } \\
\text { Plough (3) }\end{array}$ \\
\hline Cirrhosis & Blood (serum) & $+\operatorname{ADS}$ in $75 \%$ of 4 patients & Lloyd and Lobotsky (7) \\
\hline Cirrhosis & Urine & $\begin{array}{l}+ \text { ADS in } 93 \% \text { of } 15 \text { patients with ascites } \\
0 \text { ADS in non-ascitic liver disease }\end{array}$ & Sims (8) \\
\hline Hepatitis & Urine & $\begin{array}{l}\text { + ADS in } 8 \text { patients during early icteric stage } \\
+ \text { ADS decreased markedly during convalescence }\end{array}$ & Labby (9) \\
\hline $\begin{array}{l}\text { Congestive heart } \\
\text { failure }\end{array}$ & Urine & $+\mathrm{ADS}$ in $80 \%$ of 15 patients & $\begin{array}{l}\text { Bercu, Rokaw, and } \\
\text { Massie (10) }\end{array}$ \\
\hline $\begin{array}{l}\text { Congestive heart } \\
\text { failure, Cirrhosis, } \\
\text { Addison's disease }\end{array}$ & Urine & $\begin{array}{l}\text { + ADS in } 12 \text { patients with congestive heart failure } \\
+ \text { ADS in } 2 \text { patients with cirrhosis } \\
+ \text { ADS in } 2 \text { patients with controlled Addison's disease }\end{array}$ & $\begin{array}{l}\text { Dochios and Dreifus } \\
\text { (11) }\end{array}$ \\
\hline $\begin{array}{l}\text { Congestive heart } \\
\text { failure, Cirrhosis, } \\
\text { Addison's disease }\end{array}$ & Blood (serum) & $\begin{array}{l}\text { No significant difference between ADS of controls and } \\
\text { patients in failure or with liver disease. No correla- } \\
\text { tion between ADS and edema or with liver damage. } \\
0 \text { ADS in } 3 \text { patients with controlled Addison's disease }\end{array}$ & Perry and Fyles (12) \\
\hline Hypertension & Urine & $+\mathrm{ADS}$ in $73 \%$ of 15 patients & Ellis and Grollman (13) \\
\hline Hypertension & Blood (serum) & $\begin{array}{l}+ \text { ADS in } 46 \% \text { of } 56 \text { patients } \\
+ \text { ADS also in patients without hypertension, i.e., } \\
\text { malignant tumors, pregnant women, and one patient } \\
\text { with recurring duodenal ulcer }\end{array}$ & $\begin{array}{l}\text { Griffith, Corbit, Ruther- } \\
\text { ford, and Lindauer (14) }\end{array}$ \\
\hline $\begin{array}{l}\text { Bright's disease, } \\
\text { Cushing's disease, } \\
\text { Premenstrual } \\
\text { tension, Nephrosis }\end{array}$ & Urine & $\begin{array}{l}\text { Correlation between clinical edema and + ADS. } \\
\text { However, found some edematous patients with } \\
0 \mathrm{ADS} \text { and }+ \text { ADS in patients without edema. }\end{array}$ & Robinson and Farr (15) \\
\hline $\begin{array}{l}\text { Cirrhosis, } \\
\text { Congestive heart } \\
\text { failure, Hyper- } \\
\text { tension, Miscel- } \\
\text { laneous }\end{array}$ & Blood (plasma) & $\begin{array}{l}+ \text { ADS in } 28 \% \text { of } 25 \text { patients with cirrhosis with ascites } \\
+ \text { ADS in } 18 \% \text { of } 28 \text { patients with congestive heart } \\
\text { failure } \\
+ \text { ADS in } 36 \% \text { of } 25 \text { patients with hypertension } \\
+ \text { ADS in } 43 \% \text { of } 30 \text { patients with miscellaneous } \\
\text { entities }\end{array}$ & This report \\
\hline
\end{tabular}

* 0 ADS - same as controls; + ADS-greater than controls. 


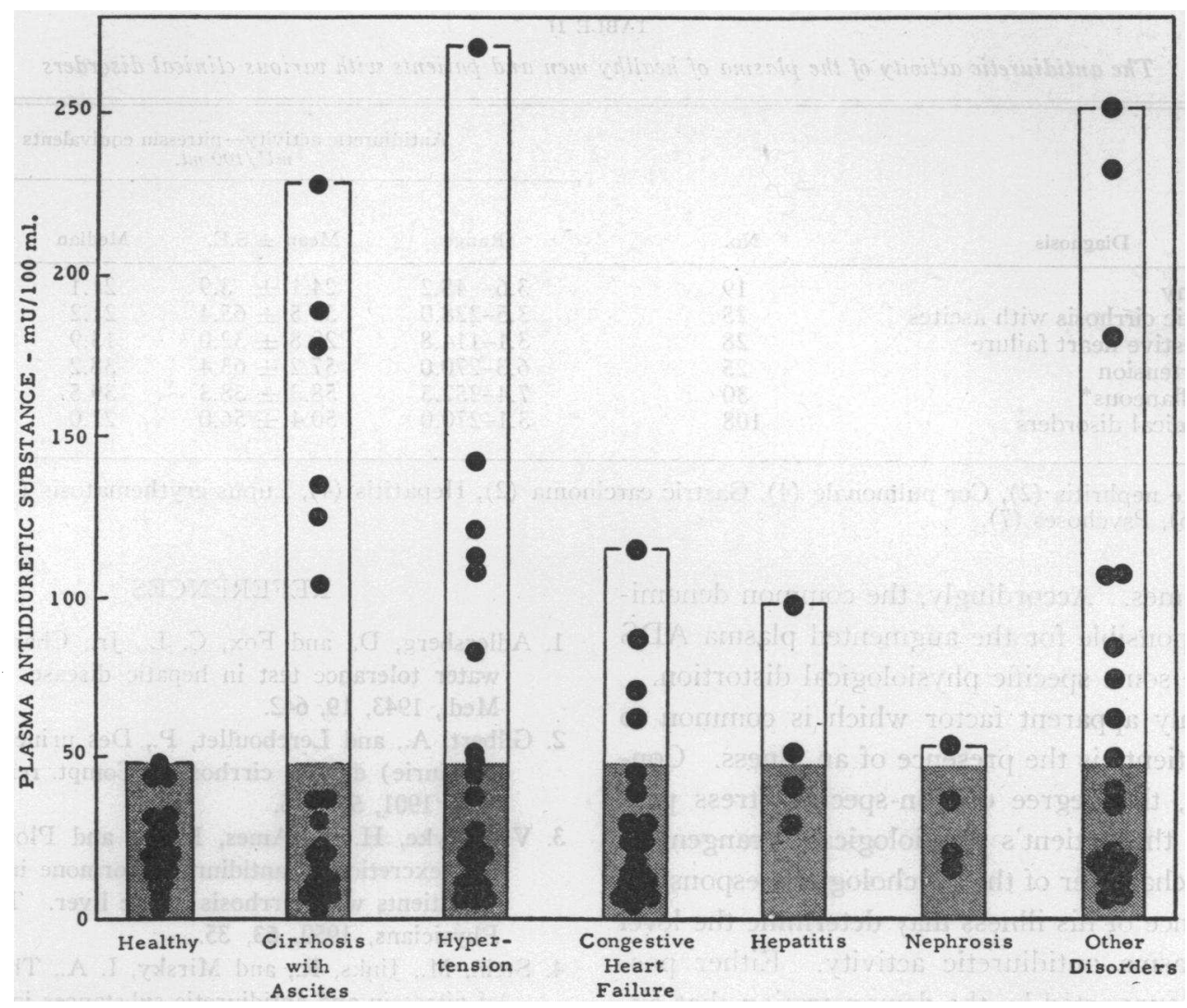

Fig. 1. The Antidiuretic Activity of Plasma from Healthy Men and from Patients with Various Clinical Disorders

of 25 patients with ascites showed an antidiuretic activity of the plasma which was beyond the range of values found in the healthy men. Likewise, the plasma ADS was increased in only 18 per cent of 28 patients with the edema of congestive heart failure. Four patients with nephrosis showed no significant deviation from the control group.

In accord with the conclusion that there is no relationship between the retention of water and the antidiuretic activity of the blood are the observations of Van Dyke, Ames, and Plough (3) that the antidiuretic activity of the urine was increased in 50 per cent of 22 patients with the ascites of hepatic cirrhosis and in 35 per cent of similar patients without ascites. Likewise, Perry and Fyles (12) found no correlation between the antidiuretic activity of the blood serum of patients with liver disease and the presence of edema.

From their observation that the antidiuretic activity of the urine was increased in 73 per cent of 15 patients with hypertension, Ellis and Grollman
(13) postulated some relationship between this syndrome and the presence of a high antidiuretic activity. Griffith, Corbit, Rutherford, and Lindauer (14) noted an increased antidiuretic activity of the blood serum in 46 per cent of 56 patients with hypertension. In the present study, an elevated antidiuretic activity of the plasma was found in 36 per cent of 25 patients with hypertension. Consequently, it appears that there is no significant relationship between the presence of hypertension and the antidiuretic activity of the blood.

The plasma ADS was increased in 43 per cent of patients with conditions other than cirrhosis of the liver, congestive heart failure, and hypertension. When all the individual disorders are combined, a similar increase is found in 31.5 per cent of the 108 patients. A chi square analysis reveals no significant difference between the incidence of patients with an increased plasma ADS in the various clinical states or between the incidence in any particular syndrome and in the combination 
TABLE II

The antidiuretic activity of the plasma of healthy men and patients with various clinical disorders

\begin{tabular}{|c|c|c|c|c|c|}
\hline \multirow[b]{2}{*}{ Diagnosis } & \multirow[b]{2}{*}{ No. } & \multicolumn{4}{|c|}{$\begin{array}{l}\text { Antidiuretic activity - } \text { pitressin equivalents } \\
m U / 100 \mathrm{ml} .\end{array}$} \\
\hline & & Range & Mean \pm S.E. & Median & $\begin{array}{c}\text { Per cent } \\
\text { beyond } \\
\text { 'Healthy' }\end{array}$ \\
\hline $\begin{array}{l}\text { Healthy } \\
\text { Hepatic cirrhosis with ascites } \\
\text { Congestive heart failure } \\
\text { Hypertension } \\
\text { Miscellaneous* } \\
\text { All clinical disorders }\end{array}$ & $\begin{array}{r}19 \\
25 \\
28 \\
25 \\
30 \\
108\end{array}$ & $\begin{array}{l}3.6-48.2 \\
3.5-228.0 \\
3.1-114.8 \\
6.3-270.0 \\
7.4-252.5 \\
3.1-270.0\end{array}$ & $\begin{array}{l}24.1 \pm 3.9 \\
55.5 \pm 65.4 \\
29.8 \pm 32.0 \\
57.2 \pm 63.4 \\
58.3 \pm 58.3 \\
50.4 \pm 56.0\end{array}$ & $\begin{array}{l}21.1 \\
21.2 \\
13.9 \\
38.2 \\
39.5 \\
27.0\end{array}$ & $\begin{array}{l}-\overline{28.0} \\
17.9 \\
36.0 \\
43.3 \\
31.5\end{array}$ \\
\hline
\end{tabular}

* Acute nephritis (2), Cor pulmonale (4), Gastric carcinoma (2), Hepatitis (4), Lupus erythematosis (1), Psychoneuroses (6), Psychoses (7).

of syndromes. Accordingly, the common denominator responsible for the augmented plasma ADS cannot be some specific physiological distortion.

The only apparent factor which is common to all the patients is the presence of an illness. Consequently, the degree of non-specific stress produced by the patient's physiological derangement or by the character of the psychological response to the presence of his illness may determine the level of the plasma antidiuretic activity. Either possibility is supported by the demonstration that exposure to a noxious stimulus results in an increase in the antiduretic activity of the blood plasma of both man and lower species (16).

\section{SUMMARY}

The antidiuretic activity of the blood plasma was measured in healthy men and in men suffering with the ascites and edema of cirrhosis of the liver, with the edema of congestive heart failure, with hypertension, and with a variety of other clinical disorders.

The incidence of an augmented antidiuretic activity of the plasma was 28 per cent in patients with the ascites of hepatic cirrhosis, 18 per cent in patients with the edema of congestive failure, 36 per cent in patients with hypertension, 43 per cent in patients with a variety of other clinical disorders, and 32 per cent in all the subjects with clinical disorders. Consequently, there was no relation between the retention of water and the augmentation of the antidiuretic activity of the blood.

\section{REFERENCES}

1. Adlersberg, D., and Fox, C. L., Jr., Changes of the water tolerance test in hepatic disease. Ann. Int. Med., 1943, 19, 642.

2. Gilbert, A., and Lereboullet, P., Des urines retardées (opsiurie) dan les cirrhoses. Compt. rend. Soc. de biol., 1901, 53, 276.

3. Van Dyke, H. B., Ames, R. G., and Plough, I. C., The excretion of antidiuretic hormone in the urine of patients with cirrhosis of the liver. Tr. A. Am. Physicians, 1950, 63, 35.

4. Stein, M., Jinks, R., and Mirsky, I. A., The bioassay of pitressin and antidiuretic substances in blood and urine. Endocrinology, 1952, 51, 492.

5. Ralli, E. P., Robson, J. S., Clarke, D., and Hoagland, C. L., Factors influencing ascites in patients with cirrhosis of the liver. J. Clin. Invest., 1945, 24, 316.

6. Hall, C. A., Frame, B., and Drill, V. A., Renal excretion of water and antidiuretic substances in patients with hepatic cirrhosis and rats with dietary liver injury. Endocrinology, 1949, 44, 76.

7. Lloyd, C. W., and Lobotsky, J., Serum antidiuretic substances and urinary corticosteroid in the human. J. Clin. Endocrinol., 1950, 10, 318.

8. Sims, J. L., A comparison of renal function with urinary antidiuretic activity in cirrhosis of the liver with ascites. J. Lab. \& Clin. Med., 1950, 36, 990.

9. Labby, D. H., Water storage in acute hepatitis. Trans. 6th Conf. on Liver Injury, F. W. Hoffbauer, ed., New York, Josiah Macy Foundation, 1947, p. 23.

10. Bercu, B. A., Rokaw, S. N., and Massie, E., Antidiuretic action of the urine of patients in cardiac failure. Circulation, 1950, 2, 409.

11. Dochios, M., and Dreifus, L. S., Antidiuretic hormone studies in patients presenting edema. Am. J. M. Sc., 1951, 222, 538.

12. Perry, W. F., and Fyles, T. W., Antidiuretic activity of the serum of normal and diseased subjects. J. Clin. Endocrinol. \& Metab., 1953, 13, 64. 
13. Ellis, M. E., and Grollman, A., The antidiuretic hormone in the urine in experimental and clinical hypertension. Endocrinology, 1949, 44, 415.

14. Griffith, J. Q., Jr., Corbit, H. O., Rutherford, R. B., and Lindauer, M. A., Studies of criteria for classification of arterial hypertension. V. Types of hypertension associated with the presence of posterior pituitary substance. Am. Heart J., 1941, $21,77$.
15. Robinson, F. H., Jr., and Farr, L. E., The relation between clinical edema and the excretion of an antidiuretic substance in the urine. Ann. Int. Med., 1940, 14, 42.

16. Mirsky, I. A., and Stein, M., The secretion of an antidiuretic substance into the circulation in response to noxious stimuli. Science, 1953, 118, 602. 